\title{
New data on the Western Transylvanides along Ampoi Valley (Southern Apuseni Mts., Romania)
}

\author{
Erika Suciu-Krausz*, Ramona Bălc* \& Florin Borbei \\ “Babeş-Bolyai” University, Department of Geology, 1 Kogălniceanu 400084 Cluj Napoca, Romania
}

Received December 2005 accepted August 2006

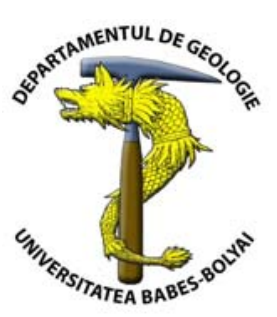

\begin{abstract}
In order to clarify some of the issues regarding the mineralogical content and the source area of the Cretaceous deposits from Ampoi Valley basin (Southern Apuseni Mountains) fourteen lithologic logs were drawn from the Ampoi Valley both side tributaries (Slatinii, Ruzi, Vâltori, Valea lui Paul, Feneş, Călineasa, Fierului Brook, Bobului, Satului, Tăuți, Galați, Presaca Ampoiului, Valea Mică and Valea Mare brooks). The main sedimentary rock types were identified (conglomerates, wacke and lithic sandstones, clays, and marls). The sandstones were classified according to the ternary diagrams. Their petrographic features revealed both a magmatic and a metamorphic source area for them.
\end{abstract}

Key words: Cretaceous, petrography, Western Transylvanides, Romania.

\section{INTRODUCTION}

The studied sedimentary deposits belong to the Cretaceous Western Transylvanides. The stratigraphic correlation of these beds is still problematic. The aim of this study is to separate the deposits based on their lithological features determined from fourteen lithologic cross-sections drawn for the tributaries of Ampoi River. Micropalaeontological study provided results for almost all the cross sections south of Ampoi River but for only one located north of Ampoi River (Fierului Brook) (Bălc, pers. comm.). Furthermore, we tried to use the petrographical and mineralogical data to separate and characterize the studied formations.

\section{LOCATION AND GEOLOGICAL SETTING}

The Ampoi River reaches the major Mureş River near Alba Iulia. It cuts the Southern Apuseni Mountains from west to east. Lithological samples have been collected from its both side tributaries. The studied cross sections are: Fierului, Feneş, Călineasa (east side tributary of Feneş), Valea lui Paul, Vâltori, Ruzi/Pietrei, Slatinii, Bobului, Satului, Tăuți, Galați, Presaca Ampoiului, Valea Mică and Valea Mare brooks.

They intersect the Feneş Nappe, the Valea Mică - Galda Nappe, Criş-Bucium Nappe and Bozeş Nappe (Bleahu et al., 1981) belonging to the Western Transylvanides (Fig. 1).

The Western Transylvanides are part of the Apuseni Mountains, together with the Apusenides. The Apuseni Mountains proceed from the Preapulian Craton and Transylvanian Tethys (Săndulescu, 1984). After the Burdigalian they were separated from the Western Carpathians and Austrian Alps by the central-Hungarian transform faults. The south-easternmost one is the Szolnok Fault and it separates the Western Transylvanides from the
Pienides. The Western Transylvanides were emplaced during the Austrian tectonic phase and reworked during the Laramian one. That is why the Western Transylvanides were divided into Austrian and Laramian ones (Balintoni, 1997).

Balintoni (2003) does not recognize the Bucium Unit (a Laramian Transylvanide) and attributes its pre-Upper Albian formations to the Feneş Nappe (an Austrian Transylvanide). The Austrian Feneş Nappe was included into Metaliferi Mountains Laramian Nappe (Balintoni, 1997).

We use the classification of the Western Transylvanides as proposed by Bleahu et al. (1981). The Feneş Nappe comprises (Lupu, 1975):

- The Feneş Formation (Bleahu and Dimian, 1967, redefined by Lupu et al., 1978). It is described as a volcanosedimentary-calcareous olistostrome with flysch sequences and it begins with a thick sequence of quartz sandstones and gray clays, which reveal olistostrome character at the upper part, marked by slumped clay-beds with interbedded tuffs and spilitic lavas. Some bioconstructed, sometimes massive, but more often thin bedded micritic limestones showing some stromatitic character are observed in the succession. The age of the formation is Barremian - Aptian (Bleahu et al., 1981).

- The Meteş Formation (Bleahu and Dimian, 1967) overlies the Feneş Formation and has a typical wildflysch character. It has an Uppermost Aptian - Middle Albian age and can be informally subdivided into 2 parts: a lower one characterized by an olistostrome-like marly-silty facies with some interbedded turbiditic and thick bedded sandstones and an upper one which consists of breccias with silty-marly variegated matrix and olistoliths representing Upper Jurassic limestones, ophiolitic rocks, granodioritic rocks, Lower Cretaceous sandstones (Bleahu et al., 1981).

- The Valea lui Paul Formation (Bleahu and Dimian, 1967 ) is predominantly detrital, coarse-grained with gray weakly lithified sandstones grading into sands. The flyschlike rhythmic sequences can be observed in the thick beds. 


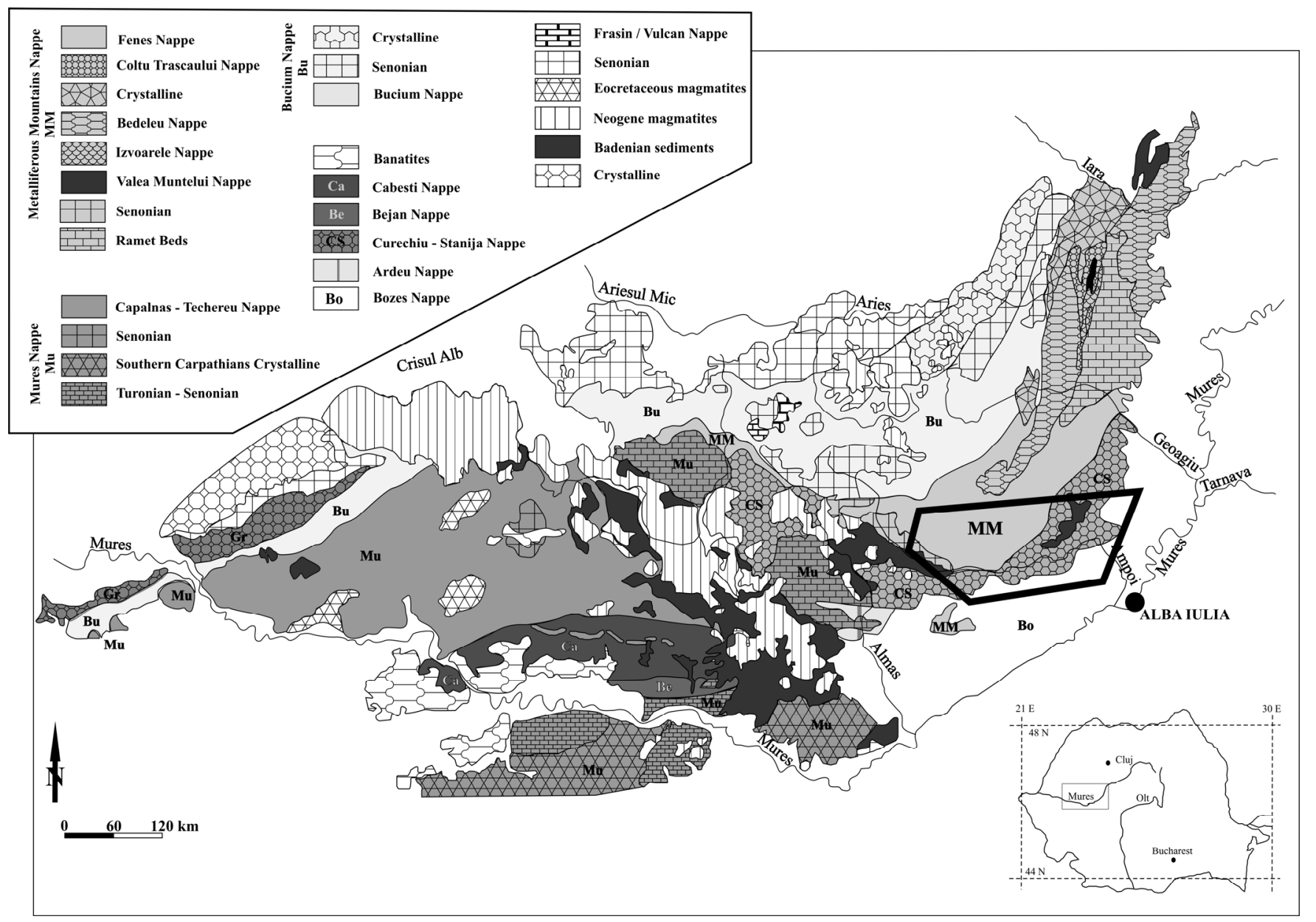

Fig. 1. Location of the studied area as part of the structural sketch of the Western Transylvanides (after Balintoni, 1997, modified).

The age of the formation is Latest Albian - Cenomanian (Bleahu et al., 1981).

- The Pârâul Izvorului Formation (Bordea et al., 1965) is of Late Albian age and initially it was considered part of the Criş-Bucium Nappe (Bleahu et al., 1981). The latest interpretation by Balintoni (2003) includes it among the cover formations of Feneş Austrian Nappe, part of Metaliferi Mountains Nappe. It consists of a silty turbiditic sequence in which the alternation of silty sandstones and silty clays is characteristic (Bleahu et al., 1981).

- The Valea Mică-Galda Nappe (Lupu et al., 1979) consists of a Senonian wildflysch megabreccia formation, in which the olistoliths belonging to the basic rocks and Upper Jurassic limestones are characteristic. The age of the formation is Turonian - Lower Senonian (Drăgănescu in Bleahu et al., 1981). Valea Mică-Galda overthrusts the Feneş Nappe and is overthrusted by the Bozeş Nappe (Bleahu et al., 1981).

- The Bozeş Nappe (Lupu et al., 1980) represents the uppermost unit among the Western Transylvanides and it is observed in the south side of the Southern Apuseni Mountains. The main lithostratigraphical component of the nappe, the Bozeş Formation (Ghițulescu and Socolescu, 1941 ) is a typical flysch formation, in which two lithologic types of successions can be seen: (1) sandstones, limy sandstones and silty marls, and (2) microconglomerates, sandstones and silty marls. The Santonian age of the sequence is based on the microfaunal data. Above the flysch-like sequence, conglomeratic levels are interbedded with silty sandstones of Campanian - Maastrichtian age.

\section{METHODS}

Fifty-one lithologic samples were collected for mineralogical and petrographic study and approximately 240 samples for calcareous nannoplankton analyses (Bălc, pers. comm.). The analytical methods used for the mineralogical and petrographical purposes were X-ray powder diffraction (Dron $3-\mathrm{Cu}$ anticathode, Ni-filtered, $2 \theta=4-64^{\circ}$ ) and optical microscopy (Nikon Optiphot2 - Pol).

In the purpose of the provenance interpretation sandstones were studied for their mineral composition and properties by using methods proposed by Dickinson et al. (1985). They demonstrated that standard QFL diagrams for plotting framework modes of sandstones can be used for the provenance interpretation of detrital material in relation to tectonic setting.

The classification of sandstones proposed by Pettijohn et al. (1987) is primarily concerned with the mineralogy of the sediment and presence or absence of a matrix and does not depend on the depositional environment.

\section{RESULTS}

The samples collected for mineralogical and petrographical study belong to the Meteş Formation (identified on Fierului and Valea lui Paul brooks), to the upper part of Feneş Formation (on Fierului, Călineasa, and Feneş brooks), to the lower part of the Feneş Formation (on Călineasa brook), to the Pârâul Izvorului Formation (on Vâltori, Ruzi/Pietrei, and Slatinii brooks) and to the Bozeș Formation (identified on all the south side tributaries of 
Ampoi Valley) according to the geological maps covering the area (Bleahu and Dimian, 1967, Borcoş et al., 1981, Bordea et al., 1979, Lupu et al., 1979).

Samples belonging to the Meteş Formation were collected from Valea lui Paul brook (samples no. 178, 185, 191, 194). Sample no. 178 is sandy breccia, the others are sandstones. Clasts are subrounded and include quartzite, micaschists, limestone, schists and amphibolites as lithic fragments and quartz, plagioclase, muscovite, biotite (iron depleted), opaque minerals, garnet (abundant), chlorite and zircon, titanite (rarely) as mineral fraction. The cement is carbonatic.

The sample collected from the lower part of the Fenes Formation (intercepted on Călineasa Brook) is reddish lithic mica sandstone (sample no. 379). Clasts are angular to round. The minerals components are quartz, plagioclase, iron poor biotite, muscovite, and argilized feldspars. Among the lithic fragments quartzite, extrusive basic rock and micaschists are noted.

In the upper part of the Feneş Formation (intercepted on Fierului, Feneş and Călineasa brooks) the schistosity and orientation of the fabric is characteristic for collected samples. Oriented micas and deformation marks are also present. The samples are dark gray phillite-like siltite (chlorite phillite) with rounded to angular clasts. The mineral components are quartz, muscovite, iron poor biotite, plagioclase, epidote, feldspars, chlorite and sericite.

Sample no. 503 was collected from Vâltori brook. According to the geological map of Romania, 1:50.000, Zlatna sheet (Borcoş et al., 1981) it belongs to the Valea Dosului Formation (Late Aptian - Early Albian). Their lithological characteristics are alike the sediments from Feneş Formation although there are no other results to prove its affiliation. Until then we will use the term Valea Dosului/Fenes Formation for the location of the sample. Sample no. 451 collected from Slatinii brook, belongs to Pârâul Izvorului Formation according to the geological map of Romania, 1:50.000, Abrud sheet (Bordea et al., 1979). The field observations lead us to include the sample also in Feneş Formation.

Most of the collected samples belong to the Pârâul Izvorului Formation. Sandstones from the turbiditic sequences are pinkish-reddish, with equigranular clasts and numerous pores. Microscopically, clasts are angular to subrounded; siliceous and limonitic pore cement and often sutural contacts are distinguished. Among the mineral components quartz, opaque minerals, muscovite, biotite (iron poor, chloritized), argilized and sericite feldspars, iron oxides, plagioclase are present. As for the lithic fragments quartzite, sericite schist, micaschist, and quartz schist are often noted. Dark gray siltite, with numerous muscovite spangles were collected from the same formation. Under the microscope, the orientation of micas is noted. Clasts are angular to subround. The matrix is phyllosilicatic. The mineral components include: quartz, sericitized feldspars, opaque minerals, plagioclase, (iron poor and chloritized) biotite, muscovite, apatite and chlorite. As lithic fragments quartzite is representative.

One sample (sample no. 515) collected upstream Vâltori brook, close to its spring, belongs to the Maastrichtian Formation according to Borcoş et al. (1981). It represents reddish quartz-mica sandstone. Component minerals are quartz, epidote, feldspar, chlorite, sericite, limonite, opaque minerals. The matrix is phyllosilicatic.

Part of the collected samples was quantitatively analyzed in order to determine the percentage of the mineral constituents (Tables 1-3).

The samples collected from the lower part of Feneş Formation have up to $15 \%$ mica and illite, quartz between 11 and $32 \%$ and feldspar between 11 and $62 \%$. Two out of six collected samples contain kaolinite, and three contain relatively high percentages of calcite (39 to 61\%). The samples belonging to Meteş Formation exhibit higher percentages of mica and illite ( 7 to $16 \%$ ), quartz (26 to $43 \%$ ) and feldspar (16-26\%) (Table 1). The percentages rise towards west where the samples belong to Pârâul Izvorului, Valea Dosului/Feneş and Maastrichtian Formations. Mica and illite range between 2 and $23.4 \%$, quartz reaches $84 \%$ and feldspar 34\% (Table 2).

The samples collected from the Bozeş Formation reach $32 \%$ mica and illite, rise to $38 \%$ quartz for the easternmost collecting sites, and to $44.4 \%$ feldspar towards west (Table 3). Calcite is present in all samples except one.

Table 1. Mineralogical content of the samples collected from the Lower part of Feneş (LF) (dark grey), Upper part of Feneş (UF) and Meteş Formations (light grey) valleys.

\begin{tabular}{cccccccccccc}
\hline Formation & \multicolumn{9}{c}{ LF } & \multicolumn{3}{c}{ UF } & \multicolumn{3}{c}{ Metes Fm. } \\
\hline Sample \#/ Mineral & $\mathbf{2 0 2}$ & $\mathbf{2 1 8}$ & $\mathbf{3 8 1}$ & $\mathbf{3 8 4}$ & $\mathbf{4 0 3}$ & $\mathbf{4 0 6}$ & $\mathbf{3 7 9}$ & $\mathbf{1 7 8}$ & $\mathbf{1 8 5}$ & $\mathbf{1 9 1}$ & $\mathbf{1 9 4}$ \\
\hline Mica + Illite & 7 & 7 & 15 & 1 & - & 9 & 3 & 14 & 16 & 10 & 7 \\
Chlorite + Vermiculite & 5 & 13 & 37 & 7 & 3 & 19 & 3 & 11 & 19 & 21 & 24 \\
Kaolinite & - & - & - & 11 & - & 8 & - & - & - & - & - \\
Quartz & 31 & 11 & 32 & 18 & 19 & 28 & 49 & 43 & 31 & 30 & 26 \\
Feldspar & 17 & 11 & 15 & 62 & 17 & 22 & 44 & 22 & 23 & 16 & 26 \\
Calcite & 39 & 57 & - & - & -61 & - & - & 6 & - & 22 & 14 \\
Dolomite & - & - & - & - & - & 13 & - & 3,5 & 19 & - & - \\
Hematite & - & - & 1.5 & - & - & - & - & - & - & - & - \\
\hline
\end{tabular}

Table 2. Mineralogical content of the samples collected from Pârâul Izvorului, Valea Dosului/Feneş (VD/F) and Maastrichtian Formations (Ma).

\begin{tabular}{ccccccccccc}
\hline Formation & \multicolumn{4}{c}{ Pârâul Izvorului Fm. } & \multicolumn{3}{c}{ VD/F Fm. } & Ma Fm. \\
\hline Sample \#/ Mineral & $\mathbf{4 3 6}$ & $\mathbf{4 5 3}$ & $\mathbf{4 5 4 a}$ & $\mathbf{4 5 6}$ & $\mathbf{4 6 9}$ & $\mathbf{5 1 4}$ & $\mathbf{5 0 3}$ & $\mathbf{4 5 1}$ & $\mathbf{5 1 5}$ \\
\hline Mica + Illite & 2 & 13 & 14 & 20 & 7 & 7 & 23.4 & 18 & 22 \\
Chlorite + Vermiculite & 5 & - & 15 & 25 & 9 & 12 & 51.9 & 28 & 6 \\
Kaolinite & - & - & - & 11 & - & - & - & - & - & 38 \\
Quartz & 33 & 83 & 37 & 24 & 84 & 39 & 15.6 & 34 & 34 \\
Feldspar & 10 & 4 & 34 & 20.5 & - & 42 & 9.05 & 19.5 & - \\
Calcite & 50 & - & - & - & - & - & - & - & & - \\
\hline
\end{tabular}


Table 3. The percentage of the component minerals from the samples collected south of Ampoi Valley (Bozeş Formation).

\begin{tabular}{cccccccccc}
\hline Sample \#/ Mineral & $\mathbf{2 2 6}$ & $\mathbf{2 2 7 a}$ & $\mathbf{2 2 7 b}$ & $\mathbf{2 4 2 a}$ & $\mathbf{2 4 3}$ & $\mathbf{2 5 1}$ & $\mathbf{2 7 8}$ & $\mathbf{3 0 1}$ & $\mathbf{3 1 0}$ \\
\hline Mica + Illite & 12 & 26.5 & 32 & 4 & 13 & 3 & 2 & 4 & - \\
Chlorite + Vermiculite & 8 & 3.5 & 8 & - & 8 & 2.5 & - & 7 & - \\
Quartz & 21 & 38 & 24 & 29 & 11 & 25 & 33 & 21 & 25.12 \\
Feldspar & 14 & 29 & 8.5 & 2 & 10 & 22 & 26 & 9 & 44.4 \\
Calcite & 43 & - & 27 & 39 & 58 & 47 & 24 & 57 & 30.48 \\
Kaolinite & - & - & - & 25 & - & - & 14 & - & - \\
Other clay minerals & - & - & 2.5 & - & - & - & - & - & - \\
\hline
\end{tabular}

The ternary diagrams of Pettijohn et al. (1987) and Dickinson et al. (1985) were used for the classification of all studied sandstone samples. According to Pettijohn et al. (1987) the collected sandstones drop into the arkosic arenites field (samples from the upper part of Feneş Formation, Maastrichtian Formation and two samples from Pârâul Izvorului Formation), and into the quartz-arenites field (two samples from Pârâul Izvorului Formation). The other studied arenites fall into the litharenite field (Fig. 2). The wacke sandstones (from Meteş, Bozeş and the lower part of Feneş Formations) belong to the lithic wacke category (Fig. 3).

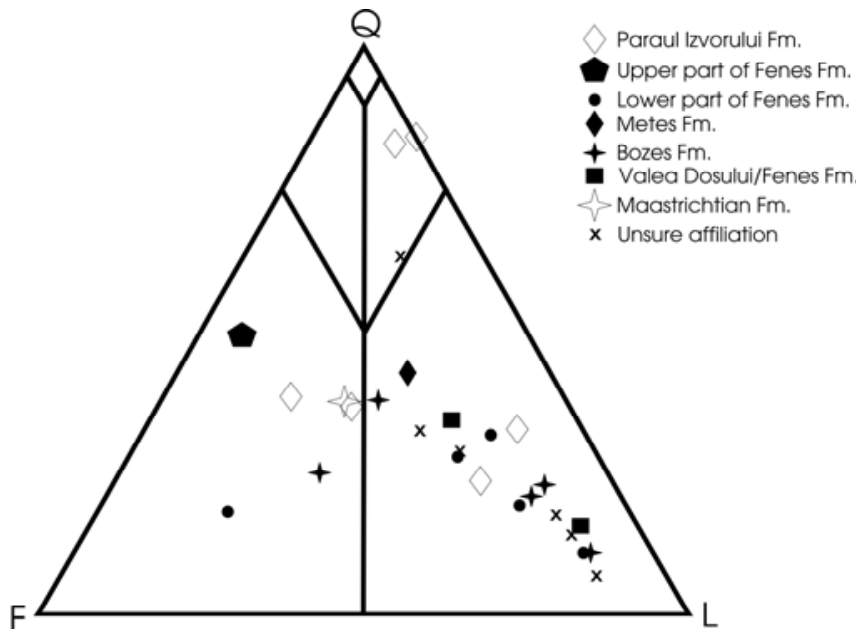

Fig. 2. Position of the arenites from the north side tributaries of Ampoi Valley in the ternary classification diagram by Pettijohn et al. (1987). $Q=$ Quartz; $L=$ Lithic fragments; $F=$ Feldspars.

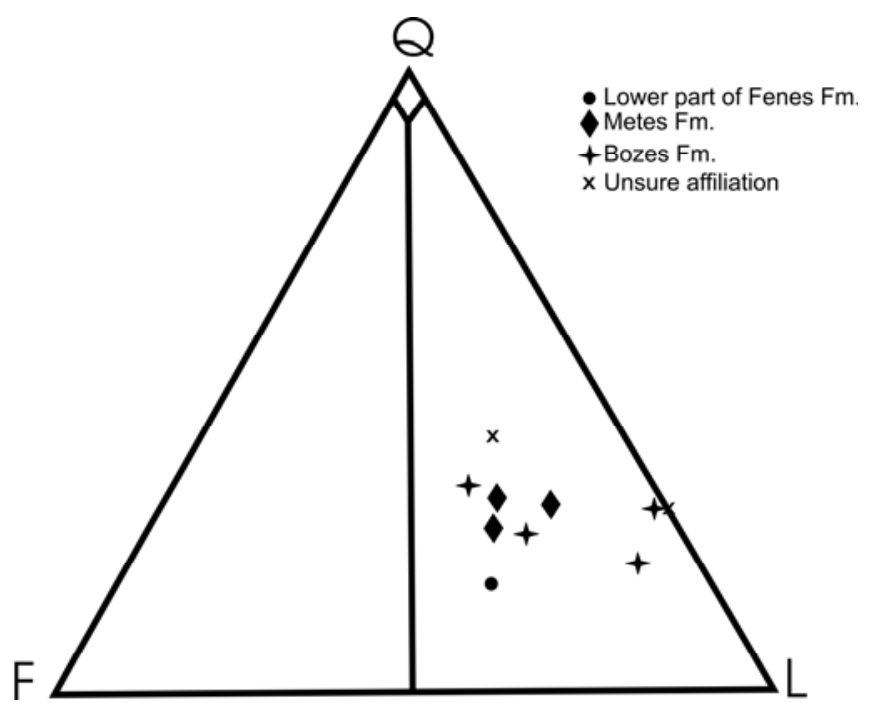

Fig. 3. Location of the wacke sandstones collected along the Ampoi Valley according to the ternary classification diagram by Pettijohn et al. (1987). $Q=$ Quartz; $L=$ Lithic fragments; $F=$ Feldspars.
The percentages of various combinations of grains are plotted on a ternary diagram (Dickinson et al., 1985) (Fig. 4) and used to discriminate sandstones from the four major tectonic settings (stable craton, basement uplift, magmatic arc and recycled orogen). The source areas for the mineral components in the studied sandstones range from recycled orogen to the various types of arc tectonic setting depending on the affiliation of sandstones to different formations. Bozeş Formation originates from an exclusive magmatic tectonic setting (either dissected, transitional or undissected arc). Sediments from Valea Dosului / Feneş Formation, the Maastrichtian Formation and the lower part of Feneş Formation have also an arc tectonic setting. Analyzed sediments from Meteş Formation belong to the magmatic tectonic setting, excepting one sample plotted in the recycled orogenic field next to the boundary with the dissected arc. The sample from the upper part of Fenes Formation is plotted in the basement uplift field. Two samples belonging to Pârâul Izvorului Formation are plotted in the recycled orogenic field, whereas the other four occupy the arc tectonic setting fields.

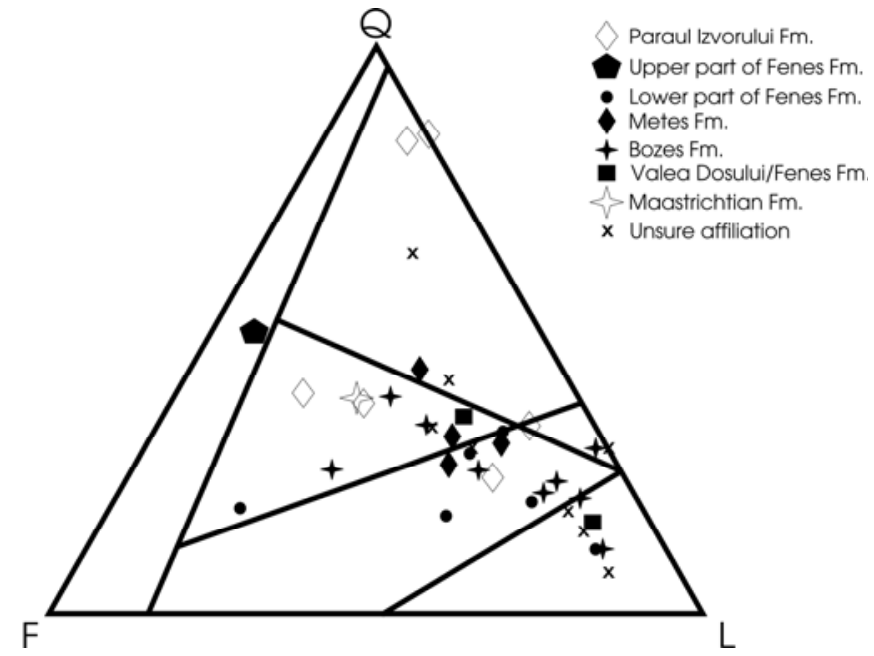

Fig. 4. The tectonic setting of the collected samples according to the ternary diagram by Dickinson et al. (1985). $Q=$ Quartz; $L=$ Lithic fragments; $F=$ Feldspars.

The label "unsure affiliation" used in the ternary diagrams regards the samples that could not be attributed to any formation due to the lack of geological maps for the collecting sites.

\section{DISCUSSIONS}

The tectonic setting of the studied sedimentary rocks varies from arc to recycled orogenic tectonic setting, with most of the sources concentrated in the arc. Two samples from Pârâul Izvorului Formation (Late Albian) are plotted into the recycled orogenic field. Therefore, the metamorphic affiliation can be regarded as the indication of the first 
metamorphic source influences in the sedimentation, as the Pârâul Izvorului Formation represents a post tectonic cover. One sample from Bozeş Formation (Santonian Maastrichtian) and one from Meteş Formation (Uppermost Aptian - Middle Albian) are plotted in the same field next to the boundary with the arc setting field. The rest of the studied formations (Bozeş, Feneş, Meteş, Valea Dosului/Feneş, and Maastrichtian) belong to the magmatic arc tectonic setting. It can be noted that the source area for the studied formations changed from an arc setting during Early Cretaceous to a metamorphic one during the Middle Cretaceous and back to a magmatic one during Late Cretaceous. The influence of the ophiolitic nappes in the sedimentation was interrupted by an orogenic input indicating that during that time the basin was located close to the craton or was already leaning on it.

The mineralogical content of the studied samples seems fairly equilibrated. The quartz percentage reaches high values for the samples belonging to Pârâul Izvorului Formation which together with low feldspar values and high illite percentages imply either a long distance from the metamorphic source area or a basin deepening. Illite is characteristic weathering product of feldspar and muscovite, mostly a diagenetic mineral found in buried marine sediments and rarely associated with hydrothermal environments.

The samples from the Feneş Formation exhibit equally high quartz and feldspar percentages associated with low mica and illite values. The magmatic source was situated relatively close to their sedimentation basin. The situation changes for the sediments from Valea Dosului / Feneş Formation where both the values of mica/illite and chlorite/vermiculite are higher in spite of the low feldspar values involving a longer period of alteration/transportation. Chlorite is an alteration product of mafic minerals (pyroxenes, amphiboles, and biotite) but can also be found associated with metamorphic minerals (low grade metamorphism) and it is characteristic to the green schist facies. All samples lack calcite. Macroscopically, samples from Feneş and Valea Dosului resemble, but the differences in the mineralogical content emphasize their separation.

The Aptian age of Valea Dosului Formation was supposed due to the superposition on the Feneş Formation and underlying the Metes Formation (Bleahu et al., 1981). Palaeontological support is needed in order to prove their exact affiliation.

Sediments from Meteş Formation display higher mica and illite percentages and low feldspar values moving the magmatic source area farther away from the sedimentation basin. Dolomite is present in samples with low calcite percentages. The sum of dolomite and calcite percentages is constant for all the studied samples from Meteş Formation leading to a possible substitution of calcite by dolomite. This theory can be supported by the lack of calcareous nannofossil (Bălc, pers. comm.). Further research is needed in order to determine the exact chemical composition of the sediments in the mentioned area and the evolution of the sedimentation and diagenesis processes.

The percentages of illite and kaolinite in sediments from Bozeş Formation increase towards east, as the feldspar diminishes emphasizing that the source area is situated towards west. In contradiction, the identified calcareous nannoplankton assemblages in the same formation (Bălc, pers. comm.) reveal an eastern proximal facies that shifts to a distal one towards west.

It is not yet possible to use the mineralogical content of the samples as diagnostic criteria in separating the formations which they belong to. Samples exhibit similarities regarding the mineralogical content as the source areas could be common. Textural and structural features (grain size, grain shape, etc) may though differ from one stratigraphic formation to the other depending on their proximity to the source area and the processes that affected their deposition and post-deposition. These characteristics are described in the results chapter. Further analyses are still required in order to discriminate between formations depending on these features.

On Vâltori brook the lithological features of the sediments remain unchanged northward the limit between Pârâul Izvorului Formation and the Maastrichtian formation drawn on the Zlatna sheet (Geological Map of Romania, scale 1:50.000, Borcoş et al., 1981). The only change in the aspect of sediments appears further upstream, close to the spring of Vâltori brook, where the grayish compact sandstone turns into a reddish one with numerous pores.

\section{CONCLUSIONS}

This paper represents an initial stage of a research campaign in Southern Apuseni Mountains. Further analyses are needed to complete the conclusion related to the Western Transylvanides along the Ampoi Valley. This implies changes in the geological maps covering the area (e.g., Zlatna sheet, 1:50000, along Vâltori brook, Borcoş et al., 1981).

Thorough chemical and petrographical analyses are also needed in order to determine features (either mineralogical or petrographical) shared by all the samples belonging to the same formation. Based on our studies we can ascertain that the mineralogical content can represent a diagnose criteria in defining the sedimentary deposits/formations but argumentation from other analyses method is required. The only petrographic certainty relates to the sediments belonging to Feneş Formation. They exhibit a characteristic schistosity which can be easily recognized throughout the lithological successions.

Palaeontological data (Bălc, pers. comm.) along with the petrographical features could contribute to the separation of the formations in the South Apuseni Mountains.

Acknowledgements. The authors are grateful to Ioan Balintoni for his help in making this study possible. Also, our thanks go to Lucreția Ghergari and Nicolae Har for their help regarding the mineralogical study. We would also like to thank all those who joined us in the field throughout the summer of 2005: Corina Fuer, Luminița Zaharia, Constantin Balica and Cosmin Stremțan.

\section{R E F E R E N C E S}

Balintoni, I. 1997, Geotectonica terenurilor metamorfice din România, Ed. Carpatica, Cluj Napoca, 176 pp.

Balintoni, I. 2003, Towards an improved model of the Laramian Transylvanides. Studia Universitatis BabeşBolyai, Seria Geologia, Special Issue: 13-20. 
Bleahu, M., Bordea, S., Lupu, M., Ştefan, A., Patrulius, D. \& Panin, S. 1981, The structure of the Apuseni Mountains, Guide to Excursion B3, XII Congress of the Carpatho-Balkan Geological Association, Bucureşti, $103 \mathrm{pp}$.

Bleahu, M., Dimian, M. 1967, Studii stratigrafice şi tectonice în regiunea Feneş - Ighiel - Întregalde (Munții Metaliferi). Dări de Seamă ale Şedințelor Comitetului Geologic, LIII (1): 281-304.

Borcoș, M., Berbeleac, I., Bordea, S., Bordea, J., Mantea, G. \& Boştinescu, S. 1981, Harta geologică a României, sc. 1:50.000, foaia Zlatna, Institutul Geologic şi Geofizic, Bucureşti.

Bordea, S., Ștefan, A. \& Borcoş, M. 1979, Harta geologică a României, sc. 1:50.000, foaia Abrud, Institutul Geologic si Geofizic, Bucureşti.

Bordea, S., Bordea, J. \& Puricel, R. 1965, Asupra prezenței Albianului în Munții Metaliferi, Dări de Seamă ale Şedințelor Comitetului Geologic, LI (1963-1964), 1: 213-215.

Dickinson, W.R., Beard, L.S., Brakenridge, G.R., Erjavec, J.L., Ferguson, R.C., Inman, K.F., Knepp, R.A., Lindberg, F.A. \& Ryberg, P.T. 1985, Interpreting provenance relations from detrital modes of sandstones. In Provenance of Arenites (Zuffa, G.G, Ed.), Dordrecht: Reidel, 333-361.
Ghiţulescu, T.P., Socolescu, M. 1941, Etude géologique et minière des Monts Metalliferes, Analele Institutului Geologic, XXI: 181-463.

Lupu, M. 1975, Einige bemerkungen zur Tektonik des südlichen Apuseni Gebirge (Siebenbürgisches Erzgebirge), Revue Roumaine de Géologie, Géophysique et Géographie, Serie de Géologie, 19: 95-104.

Lupu, M., Bleahu, M., Bordea, S., Bordea, J., Drăgănescu, A., Lupu, D., Nicolae, I. \& Mantea, G. 1978, Report, The archives of the Institute of Geology and Geophysics, Bucureşti.

Lupu, M., Berbeleac, I., Ştefan, A. \& Papaianopol, F. 1979, Harta geologică a României, sc. 1:50.000, foaia Hălmagiu, Institutul Geologic şi Geofizic, Bucureşti.

Lupu, M., Bleahu, M., Bordea, S., Bordea, J., Drăgănescu, A., Lupu, D., Nicolae, I. \& Mantea, G. 1980, Report, the archives of the Institute of Geology and Geophysics, Bucureşti.

Pettijohn, F., Potter, P. \& Siever, R. 1987, Sand and sandstone. Springer-Verlag, New York, 533 pp.

Săndulescu, M. 1984. Geotectonica României. Ed. Tehnică, Bucureşti, $336 \mathrm{pp}$.

Săndulescu, M. 1994, Overview on Romanian Geology, Romanian Journal of Tectonic and Regional Geology, 75 (Suppl. 2): 3-15. 